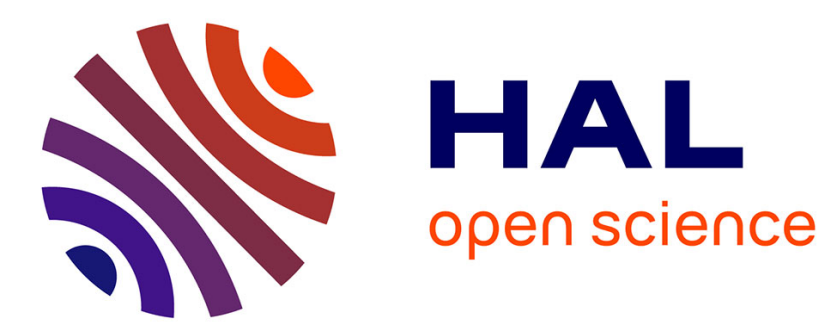

\title{
The decommodified security ratio:A tool for assessing European social protection systems
}

\author{
Georges Menahem
}

\section{To cite this version:}

Georges Menahem. The decommodified security ratio:A tool for assessing European social protection systems. International Social Security Review, 2007, 60 (4), pp.69-103. halshs-00198398

\section{HAL Id: halshs-00198398 \\ https://shs.hal.science/halshs-00198398}

Submitted on 17 Dec 2007

HAL is a multi-disciplinary open access archive for the deposit and dissemination of scientific research documents, whether they are published or not. The documents may come from teaching and research institutions in France or abroad, or from public or private research centers.
L'archive ouverte pluridisciplinaire HAL, est destinée au dépôt et à la diffusion de documents scientifiques de niveau recherche, publiés ou non, émanant des établissements d'enseignement et de recherche français ou étrangers, des laboratoires publics ou privés. 


\section{The decommodified}

security ratio:

\section{A tool for assessing}

European social protection

systems

Georges Menahem
Director of research at CNRS-CEPN, Universite Paris 13,
and IRDES
With a view to better assessment of the roles played
by social security and social policy in determining
well-being, this article introduces the "decommodified
security ratio" (DSR), an instrument for evaluating
an important duty of the social State, namely to maintain
and improve people's economic security. To that end
we describe the conventions for its use, analyse its main
components in 20 European countries in 2002 and
simulate the changes in it produced by ten variations
in those components. From an analysis of the sensitivities
of economic security we then demonstrate three different
rationales.

What will tomorrow's social protection look like? What tools can assist us in shaping it? These questions come to mind when we read the analytical article by Chantal Euzéby (2004) entitled "Rethinking social security in the European Union: Extending fundamental universal rights". The author stresses the importance of the social shifts which the countries of Europe are currently experiencing: changing patterns of work, the phenomenon she calls the "breakdown in the wage structure", developments associated with unemployment, precarious employment and exclusion, family instability and countless other factors which jeopardize the individual's security. She compares this alarming picture with more theoretical scenar-

My thanks are due to two anonymous referees and to Professor Jean Gadrey for kindly reading through this text and for their valuable comments, which prompted me to make significant improvements to my initial draft. Any remaining errors and inadequacies are, of course, entirely my own. 
ios stressing the importance of concern for security: on one hand what she calls the "postwelfarist principles of justice as understood by John Rawls and Amartya Sen" and, on the other hand, quotations from the ILO's 1944 Declaration of Philadelphia and Articles 22 and 25 of the 1948 Universal Declaration of Human Rights emphasizing the need for the individual within a society to have "economic security", "social security" and, very specifically (Article 25), "security in the event of unemployment, sickness, disability, widowhood, old age or other lack of livelihood in circumstances beyond his control".

The assumptions behind her paper are inescapable if we are to consider in greater depth the fundamental nature of the need for security, and this prompts us to think about the best ways of "shaping social security". In order both to define its broad principles and make adjustments to its methods of implementation, we need tools: theoretical tools - and Euzéby's proposals are essentially that - but political tools as well, of course; plus tools of a more statistical nature, to enable us to assess whether the means used are adequate to the ends pursued, one of those essential ends being the security of the individual.

Progress towards this latter end has already been greatly furthered by the work of the International Labour Office. In particular, the programme of research spearheaded by Standing (2002) with the aim of building a world system of "People's Security Surveys" is extremely valuable. This ambitious work enables a number of indexes of security to be devised - security of income, of skill reproduction, job, employment, union representation and so on - and aims to take account of the many dimensions of working life throughout the world.

The thrust of the present article is less ambitious in that it confines itself essentially to estimating the outcomes of social protection as delivered to citizens under social security systems in Europe. We define the economic security of the individual as that which safeguards the individual against the risk of poverty due to lack or loss of income or an inadequate income. Bearing in mind the approach conceptualized by Esping-Andersen (1990) in defining the role of the constitutional State in relation to the market, we distinguish two types of security associated with two types of resources: "commodified" security derives from "commodified" income because this arises from commercial exchanges performed either in labour markets, which fix the terms of paid employment, or in markets in goods and services which determine incomes from self-employment or from property; while "decommodified" security derives from "decommodified" income, so called because it is independent of markets and arises either from social benefit entitlements or from grants and assistance paid by virtue of a per- 
son's place of residence or situation of inadequate means. ${ }^{1}$ Decommodified security thus encompasses both social security per se and security in the form of benefits, assistance and social welfare delivered to the needy by local government and welfare organizations. ${ }^{2}$

To paraphrase wording used in the substantial work L'Etat social by Merrien et al. (2004), "the emblematic face of the social State" consists of the full range of social entitlements, the guarantee of these which state backing provides, and the actions which the State takes in the name of national solidarity. Thus, the present article takes as its starting point the links between economic security and development of the role of the social State, in proposing a tool for evaluating economic security as provided by social protection systems. This tool is the "decommodified security ratio". After a brief historical review of the interaction between social State and market forces, we present three indicators which seek to measure economic security and the "decommodification" of people's entitlements: Esping-Andersen's score, a Canadian index of security and the "decommodified security ratio". Features of this third indicator are illustrated in Table 1, which shows the components of security for a range of European social States. An estimate is then made of the multiple ways in which the decommodified security ratio is sensitive to social policy.

\section{Social construction of economic security and principles for assessing it}

Nowadays, in most European countries, most of the population is protected against the risk of poverty. But because this economic security is relative, not total, it needs to be assessed. This situation is the result of a lengthy process of social construction. The history of successive initiatives by the social State can be traced through the manifestations of material security enjoyed by the public, or rather their lack of it (Castel, 2003). Thus, if we look back to the seventeenth century and Hobbes' Leviathan of 1651, a seminal work by one of the earliest thinkers of the modern age, in nature "Man is a wolf to Man" and there is no security at all. According to Hobbes, in order to pro-

1. We disregard in this article economic security which protects against certain risks as mentioned by Beck (1986) in his Risikogesellschaft and related to natural or industrial disasters or the eventuality of terrorist attack, civil disturbance, crime or war, risks which fall within the province of civil society.

2. Referring to the definition of social protection proposed by Polanyi (1944) which recognizes three main methods of attribution (private insurance, family solidarity, and state and social redistribution) as a way of protecting workers against the effects of market forces, we should point out that our approach of decommodified security concerns only the third method of social protection as defined by this author. 
Table 1. The four components of the decommodified security ratio in 20 European countries in 2000 (\%)

\begin{tabular}{|c|c|c|c|c|c|}
\hline & $\begin{array}{l}\text { Economic } \\
\text { insecurity } \\
\text { index (EII) }\end{array}$ & $\begin{array}{l}\text { Replace- } \\
\text { ment } \\
\text { income } \\
\text { (retirement } \\
\text { pension, } \\
\text { unemploy- } \\
\text { ment) }\end{array}$ & $\begin{array}{l}\text { Reimbur- } \\
\text { sement } \\
\text { (sickness, } \\
\text { disability) }\end{array}$ & $\begin{array}{l}\text { Family } \\
\text { (housing, } \\
\text { exclusion) }\end{array}$ & DSR \\
\hline \multicolumn{6}{|c|}{ Countries of the North } \\
\hline Norway & -6.0 & 10.2 & 17.9 & 5.8 & 27.9 \\
\hline Sweden & -6.6 & 14.2 & 14.7 & 5.5 & 27.8 \\
\hline Netherlands & -6.6 & 15.4 & 14.7 & 4.2 & 27.7 \\
\hline Denmark & -6.6 & 12.5 & 11.4 & 7.8 & 25.1 \\
\hline Finland & -6.6 & 12.2 & 11.5 & 5.1 & 22.2 \\
\hline \multicolumn{6}{|c|}{ Intermediate countries } \\
\hline Austria & -7.5 & 15.1 & 10.3 & 4.1 & 22.0 \\
\hline France & -7.2 & 13.0 & 9.4 & 4.0 & 19.3 \\
\hline Germany & -9.0 & 13.5 & 10.1 & 4.0 & 18.5 \\
\hline Czech Republic & -4.8 & 9.9 & 10.0 & 2.7 & 17.8 \\
\hline Belgium & -8.4 & 13.1 & 8.5 & 2.8 & 16.1 \\
\hline United Kingdom & -10.8 & 10.8 & 9.4 & 3.7 & 13.1 \\
\hline \multicolumn{6}{|c|}{ Countries of the South } \\
\hline Portugal & -12.0 & 11.1 & 10.0 & 2.0 & 11.1 \\
\hline Italy & -11.4 & 12.7 & 7.0 & 1.0 & 9.3 \\
\hline Greece & -12.3 & 11.2 & 6.4 & 2.5 & 7.8 \\
\hline Spain & -11.4 & 9.2 & 6.4 & 0.7 & 4.9 \\
\hline
\end{tabular}

\section{Central and eastern European} countries

\begin{tabular}{llllll}
\hline Poland & -10.2 & 9.9 & 5.6 & 0.9 & 6.1 \\
\hline Latvia & -9.6 & 8.5 & 4.3 & 1.8 & 5.1 \\
\hline Slovakia & -12.6 & 7.1 & 7.5 & 2.6 & 4.6 \\
\hline Estonia & -10.8 & 6.5 & 6.1 & 2.3 & 4.0 \\
\hline Lithuania & -10.2 & 6.2 & 5.2 & 1.6 & 2.9 \\
\hline
\end{tabular}

Source: Eurostat, data available in August 2006. 
tect oneself against this absence of security, born necessarily of human beings living together in society, it was necessary to develop a strong State which would confer protection and guarantee security. The same view was voiced at the same time by Locke (1690) who held that the prime duty of the liberal State was to protect property, which provided security for the individual. Castel (2003) says à propos of this that, prior to Saint Just and Robespierre, private property was the cornerstone of security for the citizenry, to be defended by the Republic they were building. This initial feature of constitutional States, whereby security was tied to property, persists today in the structure of most industrialized States' legislation, though the economic bases which made this necessary are no longer as powerful.

\section{The State as guarantor of means and decommodified security}

In the course of the past two centuries, this duty of the social State as a guarantor of security broadly evolved as a counterweight to pressures which threaten the structure of the market, even though the advent of wage employment radically altered the bases of security by ruining a large proportion of small commercial businesses in the industrialized world. As social advances added guarantees against the risks of occupational accident, then occupational disease, retirement and unemployment, the status of the employee came to be associated with more and more types of security. Thus, in Bismarck's Germany, and then in France and the United Kingdom, the earliest social protection institutions gradually consolidated these partial securities, combining them into social security entitlements underwritten by the State and then establishing "employment" as a recognized status in law. When coalitions came to power, underpinned by the trade unions in social democratic governments in northern Europe, features of a wagebased society evolved in which the status of employment conferred lifelong securities. While in recent decades the deregulation of money markets and more fragile terms of employment have placed many of the safeguards associated with paid employment in jeopardy, nevertheless the social State continues to provide most of the social guarantees for people in the developed countries. Vital among the forms of protection which the social State has a duty to guarantee is economic security, which protects against the risk of an inadequate income.

One of the prime insecurities which people experience stems from variations in their income and other financial means. The instability of commercial activities and the resources they generate, plus the random events of everyday living, frequently endanger people's ability to feed, house and 
clothe themselves routinely and to meet their fundamental needs. In order to escape the risks of poverty, they must be protected by social security systems and guarantees of assistance from the State. These are all the more valuable in that they are unconditional and not dependent on the whims of the market or the economic climate. To this extent they are "decommodified" - to borrow the idea of Polanyi (1944) as developed and adapted to the new features of the social State in the writings of the Swedish sociologist Esping-Andersen (1990).

This author, seeking in his book The three worlds of welfare capitalism to classify and interpret the profusion of social protection systems, centred his analysis of modern States on the concept of "decommodification". He defined this idea as follows: "Decommodification occurs when a service is rendered as a matter of right and when a person can maintain a livelihood without reliance on the market" (Esping-Andersen, 1990, p. 22). This independence clearly distinguishes means which are "decommodified" in this way from the general case of subjection to market forces, which he described as follows: "When, however, labor power also became a commodity, people's rights to survive outside the market are at stake. It is this which constitutes the single most conflictual issue in social policy . . . Welfare, if not survival, came to depend on the willingness of someone to hire one's labor power" (pp. 35-36). The main thing here is to stress how this concept creates a clear distinction between commodified securities, ruled by the vicissitudes of the market and employers' decisions, and decommodified securities which, for their part, are controlled by the State and the public authorities. Looking at the work of Orloff (1993) and Lewis (1992) which examines how far decommodification changes gender relationships, we see that decommodified securities are also "family-neutral" and enable women to be less dependent on support from their families or partners, owing to the existence of separate accounts and individual entitlements for women. This analysis could be made more complex still if we introduced other social players, as Merrien et al. (2004, chap. 4, pp. 37-43) encourage us to do. The latter makes one wonder if "decommodified" means and security are not becoming social commodities appropriated by the State, trade unions and employers' organizations as part of social compromises closely dictated by the history and specific situations of each country.

\section{Two evaluations of decommodified security}

The development of numerous public bodies helping to "decommodify" security makes it increasingly valuable to have concepts and statistical tools which enable us to assess the consequences of social policy as it affects peo- 
ple's security or lack of it. To obtain a more detailed typology and illustrate its relevance, Esping-Andersen (1990) used a statistical tool which he called a "decommodification index". This was devised primarily as part of a theoretical analysis to distinguish clearly between three groups of countries, and it demonstrated that the typology used for social protection systems was sound. Can it be applied for purposes other than those originally intended? It aggregates both qualitative and quantitative variables for "sets of dimensions" which are very different and pertain to three very different areas. ${ }^{3}$ But as we do not know the conventions used to calculate the three scores of which the index is the mean, we cannot reproduce it and test it on other dates or countries. Nor, therefore, can it be used to simulate the effects of social policy changes on people's perceptions of their security or wellbeing.

Another attempt originated in the work of two Canadian research workers who devised an "index of economic well-being", which essentially seeks to show that per capita GDP is a not a good indicator of economic wellbeing (Osberg and Sharpe, 2002). The principle is to take the average of four summary indicators: the first measures consumption flows in the broad sense; the second combines considerations of economic and human "wealth stocks" and tries to take account of environmental damage; the third combines summary indicators of inequalities with indices of relative economic poverty; the fourth evaluates four types of economic insecurity related to job loss and unemployment, illness, old age and family break-up.

To measure insecurity these authors chose to evaluate individuals' subjective risk of anxiety as a result of four situations whose average cost to the individuals concerned was roughly calculable. This required them to formulate a number of approximations and an economic hypothesis which they expressed as follows: "changes in the subjective level of anxiety about a lack of economic safety are proportionate to changes in objective risk" (Osberg and Sharpe, 2002, p. 306). The cost of sickness was estimated solely as the share of uninsured private medical care expenses (which disregards loss of earnings due to time off work); the cost of loss of earnings was calculated from the gross replacement rate for unemployed workers; and the cost of divorce and old age from the mean poverty rate for lone mothers and

3. Some of these variables relate to legal factors (eligibility rules), some to institutional ones (required contributory period, duration of guaranteed entitlements and waiting time before an income can be drawn), and others are economic (level of replacement income and share of benefit costs funded by the individual) (Esping-Andersen, 1990, pp. 47-48). The appendix to the book describing this index gives neither formula nor calculation stages, so it is difficult to reproduce the decommodification index and impossible to calculate the values of each variable. 
older people (pp. 306-308). These calculations have the advantage that they produce realistic estimates of the scale of the insecurities associated with four types of economic risk. With additional approximations, 4 it is thus possible to model the variations in individuals' economic security, something which could not be done with the use of Esping-Andersen's decommodification index.

But the assessments of insecurity obtained in this way provide only very partial approximations of income loss due to sickness, unemployment, divorce or retirement. As a result, only variations in insecurity over time can be evaluated in each country. So we cannot compare respective levels of economic security in different countries of the West. Furthermore, any analysis of insecurity is very problematic because one cannot validly compare the risk from unemployment to the risk caused by sickness, divorce or old age. Once again, this other indicator cannot be used to simulate the pros and cons of variations in social policy.

\section{Principles and conventions underlying the "decommodified security ratio"}

Starting from a directly economic and global approach, our intention was to overcome the limitations of earlier indicators in order (1) to be able to compare the relative performances of the various social States in countering economic insecurity in their populations, (2) to analyse the part played by the different risk factors, and (3) to simulate the effects of different social policies on security. As pointed out by Gadrey and Jany-Catrice (2003, p. 73) at the end of an article reviewing alternative indices of development and social progress, "it is hard to see how one can do without 'questionable conventions' when dealing with the environment, quality of life and social progress, and thus with value systems. Even 'serious' economic indicators are full of questionable conventions, as witness the discussion on the major uncertainties concerning comparisons of per capita GDP in Europe." Thus, Esping-Andersen (1990) preferred an institutional approach in assessing what he called "the decommodifying potential of social policies". 5 We, however, opted for a more individually based approach to people's secu-

4. These approximations, which are not described at length in the article in question, suggest that the probability of the total insecurity risk equals the sum of the probabilities of the four risks taken into account. To accept this one must assume that the variations in the partial probabilities are additive (negative for insecurity and positive for security) and therefore that (1) their importance is marginal and (2) they are independent of each other.

5. Namely "the rules that govern people's access to benefits: eligibility rules and restrictions on entitlements": p. 47. 
rity, assessing levels of means and, in particular, estimating the level at which economic insecurity begins. It goes without saying that these two different approaches produced two different types of indicators. The conventions we adopted (see Menahem and Cherilova, 2005) need to be described in detail because they are material to our entire argument. They are listed below and reflect three main principles.

Relevant means. We decided to estimate, as means contributing to an economic security independent of links to an employer, decommodified income which derives from social protection or public assistance schemes and which people receive at different stages in their adult life. Information of this kind enables us to assess what proportion of individuals do not have an income adequate to provide them with numerous forms of security which are of prime importance, such as the ability to feed, house or clothe themselves. There are three types of such income:

- replacement income for the risks of old age, unemployment, sickness and disability plus survivors' pensions;

- reimbursements and benefits in kind: costs of healthcare, family allowances, housing benefits;

- allowances and benefits in kind paid as part of measures to combat social exclusion (income support, etc.).

Basis of comparison. For each country or territory we assessed the level of means which contribute towards security, measured against the mean disposable income of persons in employment at the location in question. This quintessential principle is based on the hypothesis that persons living in a territory measure their standard of living against that of persons deemed in the institutional and media reference system to be "standard" individuals, namely those living in the same social environment and with a job (we approximate this reference as the mean disposable income of persons in employment, specifically their income net of taxes and contributions, and inclusive of family, housing and sickness benefits). The resulting "gross ratio of decommodified economic securities" is the ratio of total decommodified income to the reference income for the territory in question.

Penalization of economic insecurity. In order to take account of the first type of economic insecurity, that of persons in poverty due to insufficient income, we took the view that the economic security of households whose per capita means are below the poverty threshold for the territory under consideration is zero and that their situation is penalized by an insecurity equal to the difference between their income and the reference income. 
In practice, the index gives a negative weight to people below the poverty line by attributing to them a negative income of 60 per cent of the mean disposable income of persons in employment. 6 This strong penalization is designed to take account of the position of needy groups whose economic insecurity diminishes their chances of well-being and survival. It also raises questions about the capacity of the institutions whose duty it is to provide individuals with a security independent of market vicissitudes. Globally, then, it has to be subtracted from the decommodified security provided by the various institutions making up the social State.

This latter principle points up the importance we were anxious to give to the objective of social cohesion, in our view a major factor in the security of a population living in a given territory. All in all, the decommodified (economic) security ratio (DSR) is both a summary and a relative indicator. Summary because it combines a gross ratio for the level of decommodified means and the level of relative poverty. Relative because it adds together the income from social entitlements which individuals receive throughout their adult life in the country concerned and divides them by a denominator which represents the average living standard of persons in employment, less the relative insecurity experienced by households below the poverty line.

Formulae for calculating the DSR. These methodological considerations all translate into accounting formulae for calculating and comparing the decommodified security levels of different populations. They can be presented in two differently aggregated forms. First, at a highly macroeconomic level, if DSR is the decommodified security ratio and EII is the economic insecurity index for persons in households living below the poverty threshold, we have:

$$
\begin{aligned}
& \mathrm{DSR}=\frac{\text { replacement incomes }+ \text { reimbursements }+ \text { benefits and allowances paid to combat exclusion }}{\text { adult population } \mathrm{x} \text { mean disposable income of persons in employment }}-\text { Ell } \\
& \text { where Ell }=\frac{\text { population in poverty }}{\text { adult population }} \times \frac{60 \text { per cent } x \text { mean disposable income of persons in employment }}{\text { mean disposable income of persons in employment }}
\end{aligned}
$$

6. This assessment of economic insecurity is close to the poverty threshold, namely Eurostat's definition of "60 per cent of the national median equivalized disposable income after social transfers", hence the adoption of this weighting which provides a system of penalization consistent with the reference income used in the denominator. One notes also that the discontinuity of the curve for decommodified economic security as determined by people's incomes is attenuated by the existence of a significant proportion of persons whose income is close to the poverty line. Given that economic security is evaluated in terms of the difference between their income and $0.6 \mathrm{x}$ the reference income, the curve first drops to zero when income reaches the poverty threshold, then falls slowly to its lowest value, $-0.6 \times$ the reference income, when income decreases further. 
A second formula produced by a partially disaggregated approach can also be put forward. The adult population can be divided into three categories according to the type of decommodified income which they receive: individuals who receive replacement incomes (unemployment or disability benefit, retirement or survivors' pensions); those who receive reimbursements and benefits in kind for their healthcare costs, or housing benefits; and those who receive benefits and allowances paid as part of measures to combat exclusion (social minima such as income support, basic old age pension and other forms of "solidarity" payment).

It is worth pointing out that there may be significant overlap between the four populations artificially picked out here: for example, some unemployed or retired persons categorized as poor may be in receipt of a pension or unemployment benefit while at the same time receiving reimbursement of healthcare costs or housing benefits and, if their income is too low to raise them out of the poverty bracket, they may be penalized in DSR terms because the last line of the formula is negative. Knowing that each population has to be weighted according to its statistical size and that we need to add to these direct decommodified incomes other indirect incomes received in reimbursement of healthcare or other costs, we can also use a second formula, as follows: ${ }^{7}$

$$
\begin{array}{r}
\text { DSR }=\% \text { retired, unemployed, disabled persons } x \frac{\text { mean replacement income (pension, unemployment) }}{\text { mean disposable income of persons in employment }} \\
+\frac{\text { mean total of healthcare reimbursements and in-kind and housing benefits }}{\text { mean disposable income of persons in employment }} \\
+\% \text { persons suffering poverty and exclusion } \\
\times \begin{array}{r}
\text { benefits and allowances paid to combat exclusion and basic old age pension } \\
\text { mean disposable income of persons in employment } \\
-0.6 \times \text { population in poverty }
\end{array}
\end{array}
$$

To check how accurately these theoretical formulae can record the real differences in security between countries, we used the databases devised and maintained by Eurostat. In so doing we took over the categories and classifications drawn up by this European organization, particularly regarding social benefits, which Eurostat breaks down into eight groups under its ESSPROS system.

7. To switch from one formula to the other, one merely needs to note that each total income figure is equal to the population concerned (i.e. percentage in the adult population $\mathrm{x}$ adult population) times the corresponding mean income. For example, for pension payments we get: total pensions $=$ pensioners as a percentage of adults $\mathrm{x}$ adult population $\mathrm{x}$ mean pension per pensioner. Dividing each of these terms by the denominator simplifies the equation by removing the adult population from numerator and denominator, thus: percentage of pensioners $\mathrm{x}$ mean pension / mean disposable income of persons in employment. 
Figure 1. Levels of decommodified security in 20 European countries in 2002

Decommodified

security ratio (DSR)

(\%)

40

30

20

10

0

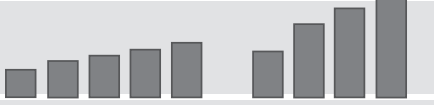

Countries

Central and eastern European countries

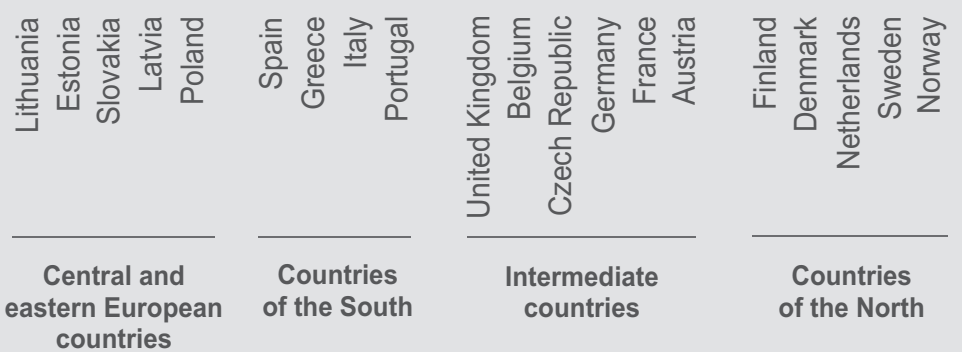

Decommodified security ratio (DSR)

= DSR benefits and exclusion

+ DSR reimbursement

+ DSR replacement

- Ell economic insecurity index

Source: Eurostat, data available in August 2006.

Note: The net DSR of 2.9 per cent for Lithuania is the difference between its low level of security-enhancing resources (13.1 per cent) and its high economic insecurity (-10.2 per cent). $h$ the United Kingdom, high insecurity (-10.8 per cent) is offset by sizeable security-enhancing resources (23.9 per cent), so its DSR is 13.1 per cent, @ur times that of Lithuania.

\section{Features of decommodified security in 20 European countries}

Eurostat figures available in late August 2006 allowed us to calculate the decommodified security ratio in 20 countries of Europe for the year 2002. ${ }^{8}$

8. The great advantage of Eurostat data is that they are provided within a consistent framework which permits international comparisons. But being supplied by the various European member state governments, they are only made available subject to specific rhythms and constraints. Consequently our tabulation contains the different variables needed to calculate the 
Figure 2. The three main factors for economic security and insecurity making up the decommodified security ratio in 20 European countries in 2002

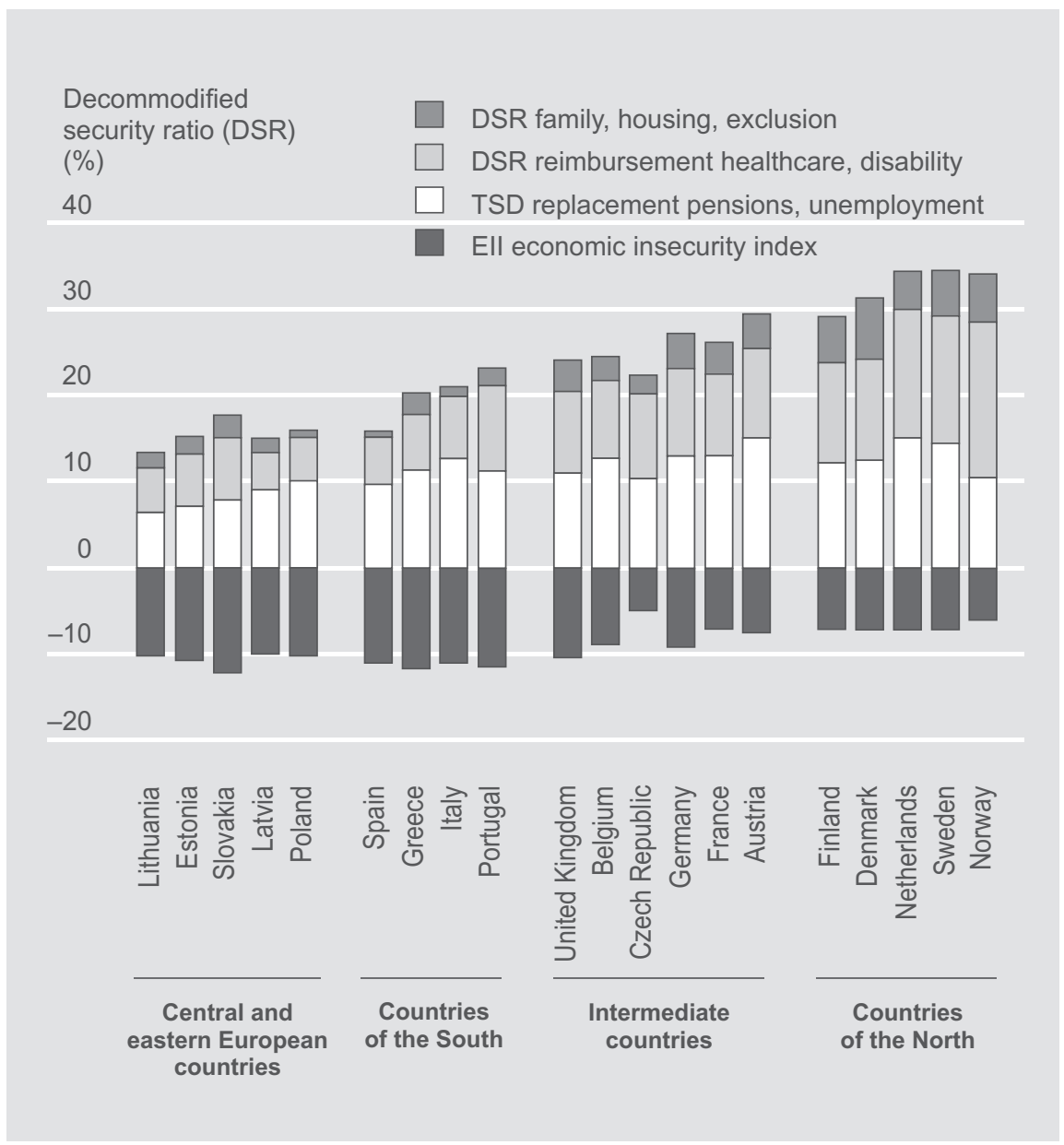

Source: Eurostat, data available in August 2006.

Note: This figure shows the positive and negative factors which determine decommodified security. Thus, in Spain in 2002, the DSR is just 4.9 per cent of the mean disposable income of persons in employment, i.e. the sum of securities for retirement and unemployment (9.2 per cent), sickness and disability (6.4 per cent), benefits to families and disadvantaged persons ( 0.7 per cent), and less insecurity (11.4 per cent). By contrast, in Norway it is 27.9 per cent of the mean reference income, or five times higher in that same year (with, respectively, securities of 10.2 per cent +17.9 per cent +5.8 per cent, less insecurity of 6 per cent).

[ 8 cont.] DSR in years 1995-2002 for 20 countries only. This is seven countries more than in our previous article (Menahem and Cherilova, 2005) for years 1995-2000 using data from 2004. It should, moreover, be noted that Eurostat relies on the eight-function ESSPROS classification of social benefits devised and harmonized for the NewCronos database. Notwithstanding the limitations of this classification, it has the advantage of allowing us to compare systems which differ widely in the nature of their inherent social entitlements, the content of the benefits they provide or the orientation of the policies underlying them. 
These estimates, reproduced in Figure 1, reveal sizeable differences in the security levels of European populations, with four groups of countries emerging as homogeneous in terms of economic guarantees. The breakdown of sources of economic security listed in Table 1 and depicted graphically in Figure 2 gives us a better understanding of the origins of these disparities which can be traced back to the institutional history of these countries. After a brief account of the limitations of our estimates we then set out to analyse our conclusions.

\section{In terms of decommodified security, European countries in four main groups}

The wide diversity of outcomes of European social benefit systems is clearly apparent in Figure 1. A historical divide can be seen between the countries of the North, mainland Europe plus the United Kingdom, whose social protection systems have made great strides in the past 50 years and more, and the countries of the South and the central and eastern European countries (CEEC) where systems of protection are still rudimentary or far more recent. In the former main group, decommodified security ranges from 13 to 28 per cent of the mean disposable income of persons in employment, whereas in the second group it is only 3 to 11 per cent. But the second group is far from homogeneous and three quite distinct subgroups can be identified within it.

We would point out here that the typology used for the decommodified security ratio is largely compatible with that of Esping-Andersen (1990). The group of the countries of the North equates essentially to the group of countries which Esping-Andersen calls "social democratic", and the group of countries labelled "intermediate" is very close to his "conservative" group, with two notable exceptions out of ten countries: Italy is classed as conservative but is not in the "intermediate" group, and the United Kingdom is part of the intermediate group but is classed as "liberal". ${ }^{9}$ Because our estimates were for European countries only and Esping-Andersen did not consider other countries of the South or the CEEC, this comparison could not be taken further.

9. In Esping-Andersen's classification (1990, p. 52), Italy has a decommodification index of 24.1, so the author places it in the "conservative" category, ahead of the United Kingdom with 23.4, which he categorizes as "liberal". The DSR gives less weight to historical institutional variables and the total value of decommodified means is the sole objective criterion for classification. This explains why the DSR for the United Kingdom is 13.1 per cent, well ahead of Italy's (9.3 per cent), and that the United Kingdom is in the group of intermediate countries while Italy is in the countries of the South group (Menahem, 2006, p. 328). 
Thus, the five "countries of the North" with the highest DSR are part of the same social democratic tradition of active state measures, generous benefits and universal coverage, even if they did not react to the crisis of the 1990s with the same reforms. 10 Their DSRs reflect the similarities of their type of social State: in 2002, between 22.2 and 27.9 per cent. The group of the "intermediate countries" is far more heterogeneous, however, because it includes one advanced former socialist country (the Czech Republic) and four countries which in Esping-Andersen's classification (1990) are "conservative" - Belgium, Germany, France and Austria - plus a "liberal" country, the United Kingdom. The scatter of their DSRs is somewhat greater, from 13.1 per cent for the United Kingdom to 22 per cent for Austria.

The group of the four "countries of the South" exhibits numerous shared features. Here, poor development of the social State has long gone hand in hand with traditions of cronyism and corporatism, so producing varying kinds of obstacles to reform. Thus, Greece, Italy, Spain and Portugal each in their own way combine the development of their financial transfers on a corporatist basis with poorly developed benefits and services to families and those in poverty, and the development of family networks to make up for these inadequacies. ${ }^{11}$ It is striking, over and above this variety, that these four countries share a similarly low level of decommodified security: from 4.9 per cent for Spain to 11.1 per cent for Portugal.

Why is the difference in DSR between Spain and Portugal so large? This may be explained in part by the different ways in which the workforce is mobilized in the two countries: first, the employment rate is far higher in Portugal (49.3 per cent of the total population in 2002) than it is in Spain (39.4 per cent), while the Portuguese social security system has a greater capacity to collect contributions and provide a high level of decommodified benefits. Another peculiarity is that there are far more women in employment in Portugal (46 per cent of the working population in 2002) than in Spain (40 per cent). These facts demonstrate a greater commitment by the social State towards decommodified provision of care for children and the elderly population in Portugal, where there are more working women.

The CEEC group also shows a homogeneity born of history. The five social States concerned all emerged from the same socialist system, have all

10. Cf. the full account of the changes in the "Scandinavian welfare state" in the special issue of Revue française des affaires sociales presented by Strobel (2003), which reproduces the papers given at a colloquium organized by MiRe.

11. Cf. the other set of writings from the "Rencontres de Florence" organized by MiRe under the title "Comparer les systèmes de protection sociale en Europe du Sud", and the concluding contribution written by Rhodes and Palier (1997). 
from differing dates onwards begun the same process of transition to a market economy and have joined the European Union. Although their social security systems were shaped historically in a manner specific to each of them individually, it is remarkable that their DSRs are similarly low, ranging from 2.9 per cent for Lithuania to 6.1 per cent for Poland. The low level of DSRs in the CEEC prompts two questions: how is it so low when prior to 1989 the socialist regimes in these countries provided the whole population with a minimum level of security? And why is the DSR at least 11 per cent higher in the Czech Republic when that country has so many historical characteristics in common with the other CEEC? First, it was only 15 years ago at most that a start was made on transferring the financing of pensions, healthcare and the main social benefits, previously done by the socialist State in the CEEC, to a system based on social security contributions. And that is a process requiring radical reorganization which will take a long time. This process of making up ground has been made more difficult by a resistance to taxation engendered by higher contributions, which place a burden on employers and private individuals, and by the fact that employers now no longer provide a number of social benefits. The Czech Republic's better DSR is due in the main to the greater growth in that country of "health funds", which finance the healthcare system on a decentralized basis, and to more vigorous economic growth since 1994 resulting in better reduction of poverty.

\section{Links between the features of the three main components of decommodified security, and economic insecurity}

The structure of the DSR is analysed numerically in Table 1 and graphically in Figure 2. This analysis leads us rapidly to four findings: the first three concern decommodified means shown as positive values above the horizontal axis and varying from 13 to 34 per cent; and the last shows the levels of economic insecurity as negative values below the horizontal axis, from 5 to 13 per cent.

1. Replacement incomes vary little. These are retirement pensions, survivors' pensions, unemployment benefit and jobseekers' allowances. Their importance depends on historical tradition, the local economic climate and the ability of trade unions, employers and the State to negotiate social compromises. With the difficulties of setting up new contributory social security systems, this explains why the level of these types of security is still quite low in the recently formed social fabric of the central and eastern 
European countries - at most 10 per cent, as in Poland and the Czech Republic. In the countries with a long-established corporatist tradition, however, these decommodified securities are high, for example in Austria and the Netherlands (15 per cent), in Sweden and Germany (14 per cent), or in France, Italy and Denmark (13 per cent). But at the same time these similar levels may conceal differences, for example between Danish motivation and drive, and corporatist traditions in Italy.

\section{Incomes from the reimbursement of healthcare and disability expendi-} ture vary more. The traditions of the Scandinavian countries whereby the State funds the majority of healthcare and provides generous disability benefits are very different from the fragility of the new systems being built in the CEEC. The Nordic countries earmark 11 to 18 per cent of their spending for this while the CEEC spend only 4 to 8 per cent. Between these extremes, the countries of the South, the United Kingdom and the countries of mainland Europe oscillate between generosity and reforms aimed at cutting the costs of healthcare.

3. The greatest variability is in benefits to families and those in poverty. These benefits total almost 8 per cent in Norway as against less than 1 per cent in Poland. In the countries of the South and the CEEC, where these securities are no higher than 2.5 per cent, family networks obviously make up for inadequacies in state provision. But the securities created in this way are less certain as they depend on personal relations.

4. The results on poverty partially reflect differing levels of decommodified means. In the countries of the North, where income guarantees are less dependent on the labour market and social policies seek rather to cover people by virtue of their entitlements as citizens, groups with an income below the poverty threshold are relatively small. Likewise, in the four "intermediate" countries of mainland Europe, state assistance is rooted in more solid traditions. Thus, there are lower levels of economic insecurity in these two groups of countries: 6-7 per cent for the Netherlands/Finland, and 7-8 per cent for France/Germany. In the United Kingdom and Portugal, however, where security depends more on the labour market, and social benefits are more of a safety net, penalization for economic insecurity is almost twice as high: 11-12 per cent. It is also significant (11-13 per cent) in the other countries of the South, where redistribution is still limited. In the central and eastern European countries too, the sizeable reduction in public benefits provided by the State, the increasing number of unemployed persons no longer covered by employers and the late emergence of a meagre social pro- 
tection "safety net" are creating high levels of economic insecurity of 10 to 13 per cent. 12

\section{Advantages and limitations of classifications based on decommodified security}

We find that the decommodified security ratio has three prime advantages when we compare the analyses of social systems based on the DSR with those using either Esping-Andersen's decommodification index or the security component of Osberg et Sharpe's index of economic well-being: (1) it permits comparisons of the social systems of different countries whose levels of development may be very unequal; (2) it helps to analyse the extent to which various social benefits contribute towards the economic security of a country's nationals, both one benefit compared with another and all benefits together; and (3) it enables us to simulate the effects of variations in economic and social policy. But these practical advantages have to be weighed against the DSR's considerable limitations.

Initial uncertainties in the tables and figures reflect the inadequacies of the Eurostat data when it comes to assessing decommodified income. Specifically, the global nature of the eight social protection functions in the ESSPROS classification means that some cash benefits or benefits in kind associated with the functions "unemployment", "survivors" and "old age" are categorized as replacement income and not as benefits. Moreover, the Eurostat classification aggregates all income which goes into the formation of retirement pensions, regardless of whether the schemes concerned are pay-as-you-go or funded schemes, and this introduces a measure of fuzziness into intercountry comparisons of decommodified income. The global nature of the "sickness" and "disability" functions in the ESSPROS classification also means that this category includes replacement income corresponding to disability pensions and the per diem benefits paid for time off work due to sickness. This further reduces the accuracy of our breakdowns.

In addition to these factors, the ultimate impact of which is yet to be assessed, there are other limitations which result from structural differences in the breakdown of employment, reflecting societal choices in the different countries: differences between generations (young people starting work relatively late, older people stopping work relatively early), differences be-

12. It is significant that the country classification by Corak (2006) based on child low-income rates in the early years of the new millennium, using data collected for the OECD by Mira d'Ercole and Förster (2005), echoes the classification based on the DSR: only Greece, Poland and Spain do better when classified according to child income rather than according to the DSR. 
tween men and women and between part- and full-time working. These three criteria are largely interdependent and significantly affect mean income in a country because of differences in pay between men and women, young and older people, full- and part-time workers. For example, the higher proportion of women and older people in employment in Portugal, the United Kingdom and the countries of the North is reflected in two factors which produce a higher level of economic security in these countries: a higher overall employment rate, which means higher total contributions, and lower mean levels of pay, which means a lower DSR denominator.13 More part-time working in the Netherlands, the countries of the North and the United Kingdom has a similar effect and helps to push up the figures for economic security in these countries.

In the countries of the South such as Italy, Spain and Greece and in the central and eastern European countries, moreover, a very significant phenomenon is that of the proportion of undeclared illegal working. This is a sizeable phenomenon in France too, leading to considerable uncertainty about the proportion of the population actually in work. This fuzziness causes varying underestimates of the DSR which are hard to assess, but it is reasonable to suppose that security will more likely be underestimated in the countries of the South than the North.

Unequal rates of main residence ownership, more unequal in the South of Europe than in the United Kingdom or the countries of the North, relate to older people more than to younger households. These rates thus cause the incomes and benefits paid to persons not in work to be underestimated to a greater degree in the South than in the North, which helps to reduce the DSR more in the South than in the North. Furthermore, it ought to be possible, in more extensive assessments of economic insecurity, to take account of the economic insecurities associated with rented accommodation, temporary housing or homelessness.

More fundamentally, in defining the DSR, the conventions used to establish the nature of the reference income against which the various decommodified means and economic insecurity are measured are extremely important. They have been partially justified above. But they remain arbitrary and many alternatives could usefully be tested: mean income for all house-

13. From this point of view it would be interesting to assess mean income levels for comparable age, gender and working time structures, something that would enable us to measure how far these societal choices influence the relative classification of decommodified security levels. Likewise, calculations of per capita GDP would shift markedly as a result. Because the calculation of GDP volume is constant, this just means in effect that the level of relative prices would be changed by an operation of this kind, reflecting the link that exists between societal choices and both labour productivity and the methods of income distribution in each country. 
holds, or median income, either in confining oneself to the employment component, as in our calculations, or in considering all forms of income.14 The simulations described below demonstrate the implications of these choices.

\section{Main results of DSR simulations for 20 European countries in 2002}

Social policy actors might ask themselves what the effects would be on people's security of increasing retirement or unemployment benefits or spending on the reimbursement of healthcare costs. They might also wish to compare the results of this spending on security with the result obtained if incomes are increased by a specified pay rise to employees. We sought answers to these questions by performing ten simulations of the factors which determine the DSR.

\section{Method used}

In order to assess the sensitivity of the DSR to variations in social benefits or private individuals' incomes, we simulated a range of alternative social policy scenarios. We took as our reference situation the position of the 20 European countries in 2002, as portrayed in the Eurostat figures. By varying just one of the ten parameters measured by 1 per cent from the 2002 values, it is possible to calculate the elasticities ${ }^{15}$ of economic security in response to variations in the ten factors (seven different social benefits and three types of income). It should be remembered here that income from paid employment, self-employment and property constitutes the three main components of the disposable income of persons in employment, and this refer-

14. There is not room in this article to explore the various tests which might remedy these inadequacies. These could be covered in a future publication.

15. Elasticity is the measure of a given object's sensitivity to a force or pressure. In economics we talk of the elasticity of demand for a good or service depending on a range of factors (income levels, prices, etc.). We calculate elasticity by determining the relationship between relative variations in the variable under consideration and those in the factor we wish to study. To determine the elasticity of economic security in relation to pension amount, the formula is: elasticity of economic security = relative variation in economic security / relative variation in pension amount. For example, all other things being equal, if a 1 per cent wage increase in Poland produces a 1.2 per cent drop in security, the elasticity of security in relation to income is -1.2 . In this case, the percentage drop in security is greater than the percentage income increase, and security is deemed to be "income-elastic". But if a 1 per cent increase in family benefits produces a smaller percentage increase in security $(+0.12$ per cent), the elasticity of security in relation to family benefits $(0.12)$ is less than unit; security is thus deemed "inelastic" in respect of this benefit. 
ence forms the denominator against which decommodified means are estimated. 16

Variations in the elasticity of security are the response to two distinct effects: one, the direct effect of benefit supplements which increases the numerator; and two, the indirect effect caused by altering the reference level against which security is measured, which changes both the denominator and the estimated economic insecurity level of persons living below the poverty threshold. Comparison of these two effects will help us to understand the variations in the DSR which our social policy simulations produce.

\section{Analysis of the simulation results}

Two general findings emerge from an analysis of the results in Table 2 . The table's ten columns show the elasticities of the decommodified security ratios calculated for a 1 per cent variation in each of the seven main social benefits and each of the three main types of direct income, each factor being assumed to vary on its own and without altering the employment rate. The 20 European countries are ranked in descending order of their DSR (the 2002 figures are given in the second column from the left).

Security gains rise as the DSR falls. Generally speaking, security gains measured by elasticities are seen to be greater, the lower the initial level of the DSR. This phenomenon is hugely important bearing in mind the social cohesion objectives of the Lisbon strategy adopted by the European Union in 2000. We can verify it for decommodified benefits paid only to persons not in employment (the effects of which operate only through changes in the numerator), for universal benefits paid regardless of whether people are in employment or not, and for the various forms of commodified income (the effects of which operate essentially through changes in the denominator).

Variations in elasticity are governed by three distinct mechanisms. The columns in Table 2 are arranged from left to right in decreasing order of independence from the market, from pensions and unemployment benefits (the benefits which are the most independent of employment income), through to income from occupational activity and property. We shall observe this order in analysing the respective parts which direct and indirect factors play in variations in economic security, and we shall see that these factors obey three different rationales.

16. In order to take account of the variations in security created by the tax burden from taxable income supplements, we endogenized the total amount of tax payable by assuming the tax rate to be constant and equal to that of the reference situation in the country in question in 2002. 


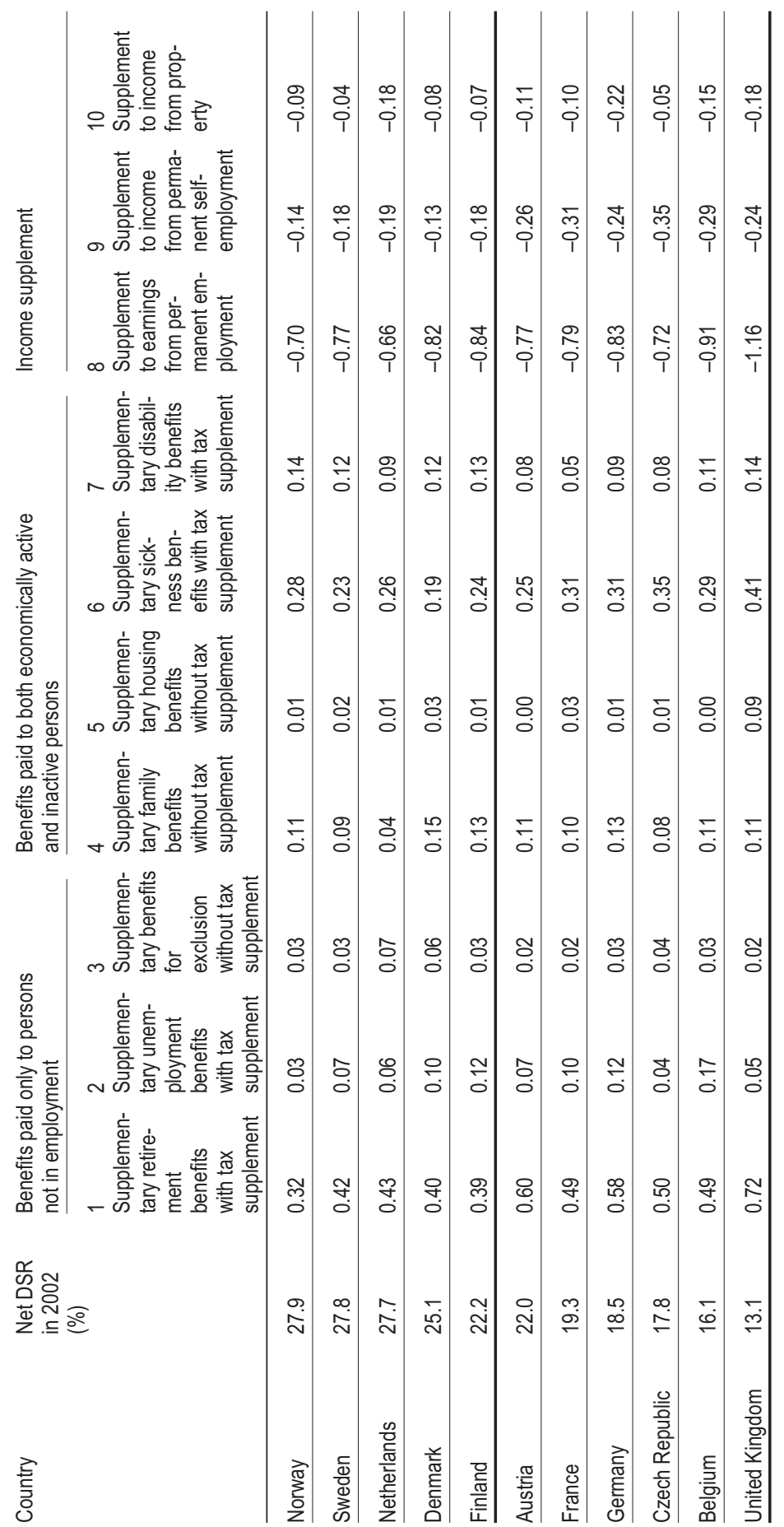

International Social Security Review, Vol. 60, 4/2007 C C 2007 The author(s) Journal compilation @ 2007 International Social Security Association 


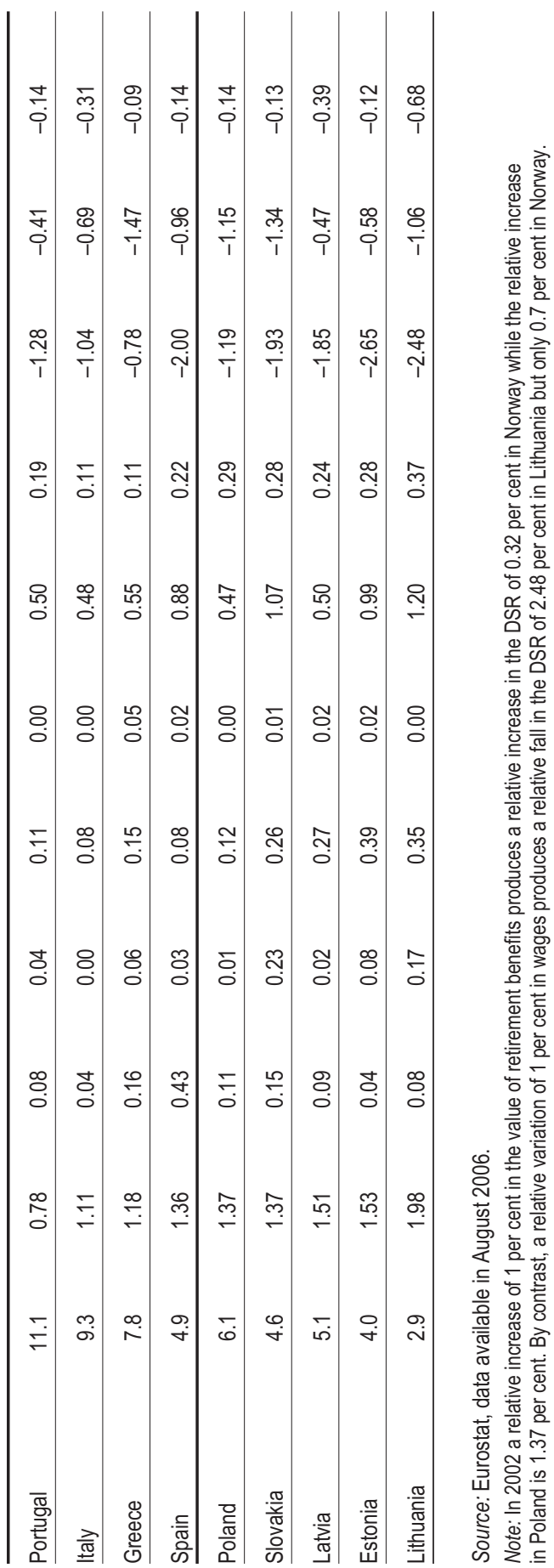


1. Benefits paid only to persons not in employment. Increases in these benefits, which are targeted at persons who are not working (unemployment and old age), have the greatest security-enhancing effect, all the more so when these benefits are expanding in a country where social coverage is generally low (countries of the South and the central and eastern European countries: cf. last 9 rows of Table 2). Unemployment and old age benefits are in fact decommodified benefits par excellence in that they are paid only to persons who are no longer part of the workforce and they have no direct impact on the income of persons in employment. Thus, their contribution to the DSR varies only with increases in income as represented in the numerator.

Benefits paid as part of measures to combat exclusion (column 3) contribute to the DSR in the same way, being paid only to persons not in employment; so they only have an effect through the DSR numerator. Once again, these are more important in Slovakia and Lithuania, countries where these benefits are as yet poorly developed, though the figures are lower than for pensions or unemployment benefits. Note too that the security-enhancing role of an identical increase in benefits is weighted by the standard of living: the lower this is, the more an identical increase in income support, for example, will translate into a greater increase in security, and thus into greater elasticity.

To illustrate these calculations we have envisaged examples which are plausible under current social conditions: 2 per cent growth in retirement pensions or 2 per cent growth in unemployment benefit. In Poland, for example, a 2 per cent increase in pensions in 2002 would mean a 2.7 per cent increase in the DSR. Whereas in Denmark, where the standard of living and pension levels are much higher, this same increase would raise the level of decommodified security by only 0.8 per cent. If unemployment-related public spending, already high in Denmark (one quarter of pension spending), were to increase by 2 per cent, the DSR would rise by only 0.18 per cent (again, a quarter). But in Poland, the enhancement of decommodified security brought about by this same increase would be only 0.23 per cent, because unemployment benefits make up a far smaller proportion of total social benefits in that country.

2. Benefits paid regardless of employment status. Sickness and disability benefits (columns 6 and 7) are universal benefits paid both to persons who are working and those outside the labour market. In countries where such benefits are virtually non-existent (countries of the South and the central and eastern European countries), their security-enhancing effect (DSR) is very considerable. It is, however, less significant than that of benefits paid only to unemployed persons. The influence of universal benefits is dimin- 
ished by the fact that they help to increase the reference income of those in employment, the level of which affects both the DSR denominator and the estimate of economic insecurity.

Family and housing benefits (columns 4 and 5) are paid both to persons who are working and those who are outside the labour market, but they are often means-tested. The effect on the DSR of any increase in these is thus more limited because the increase in their contribution to the numerator is smaller and is, moreover, partially offset by the fact that these benefits are added to the incomes of those in employment, which increases the reference income and thus the denominator too. Because these benefits are currently very limited in the countries of the South and the CEEC, their contribution to the DSR in these countries is greater.

3. Incomes from economic activity and property. Supplements to wages and salaries, however, assuming a constant number of persons employed and a rising standard of living for economically active persons, translate into a reduction in decommodified security (DSR). Why is this? Because these increases entail a rise in the reference income, which enables us to measure both economic insecurity and the decommodified security created by benefits. When the standard of living rises, the decommodified security created by a certain level of benefits relative to the reference income falls. Table 2 shows that the lower the denominators concerned are, the more this security decreases: and it decreases more in the countries of the East or the South than in Scandinavia. A second major effect depends on the numerator: this is the increase in economic insecurity which penalizes decommodified security in proportion to the poverty rate and reference income.

These two factors account for the negative elasticities for income from economic activity and property (Table 2 , last 3 columns on the right). Income from property (column 10) is shared between persons who are economically active and those who are not, and it thus has less of an effect on the reference income; this explains why these elasticities are lower than those for self-employed income, though the incomes are comparable.

Income from paid employment (column 8) accounts for the largest share of the reference income, which is why the elasticities for this are always the greatest. There is one exception, Greece, where the proportion of informal work is very high and recorded incomes from self-employment exceed those from paid employment. The far smaller elasticities of the northern countries compared with those of the central and eastern European countries, the countries of the South or the United Kingdom are explained both by higher income levels in those countries, which raise the reference standard of living accordingly, and by their lower poverty rate. Compared with 


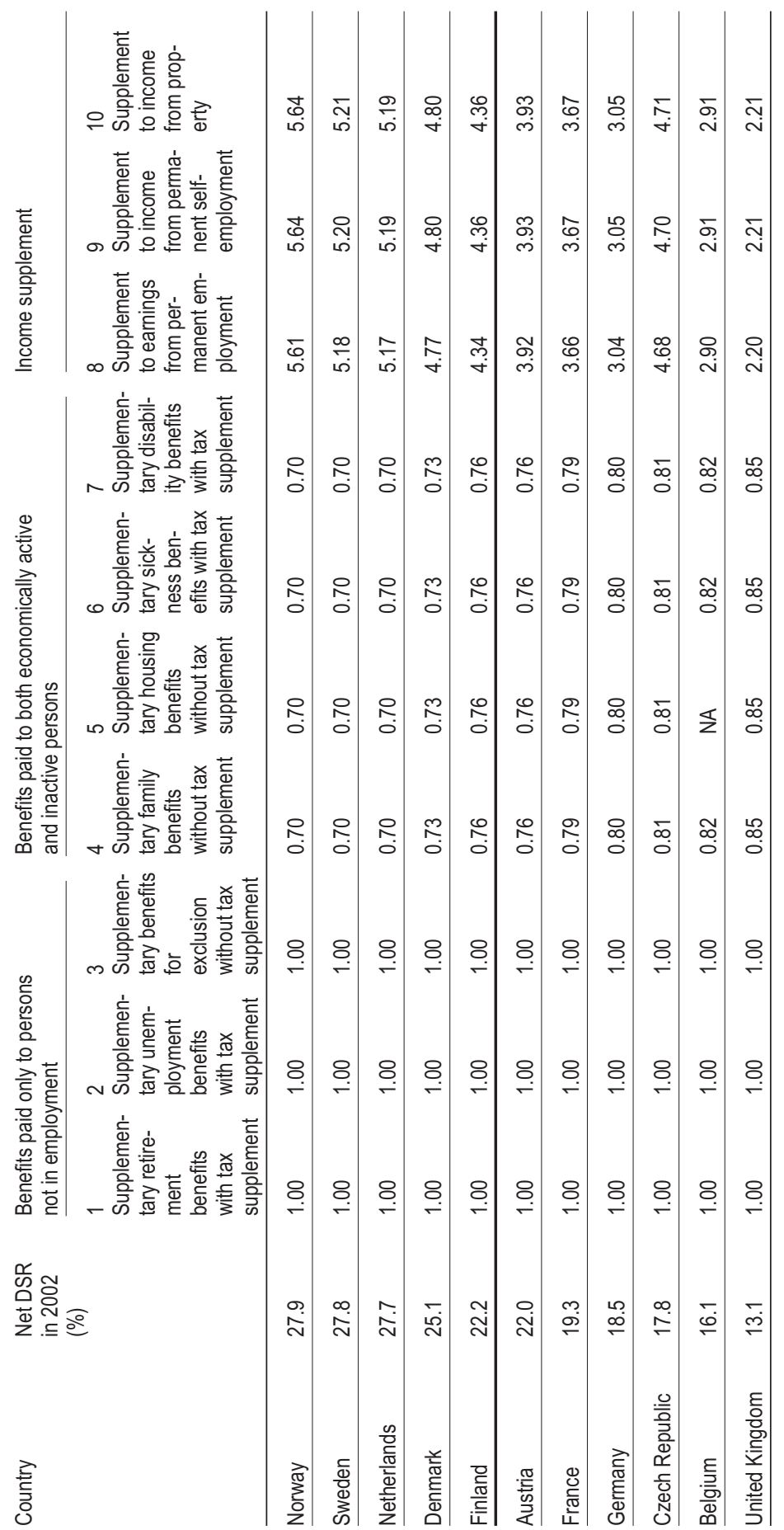




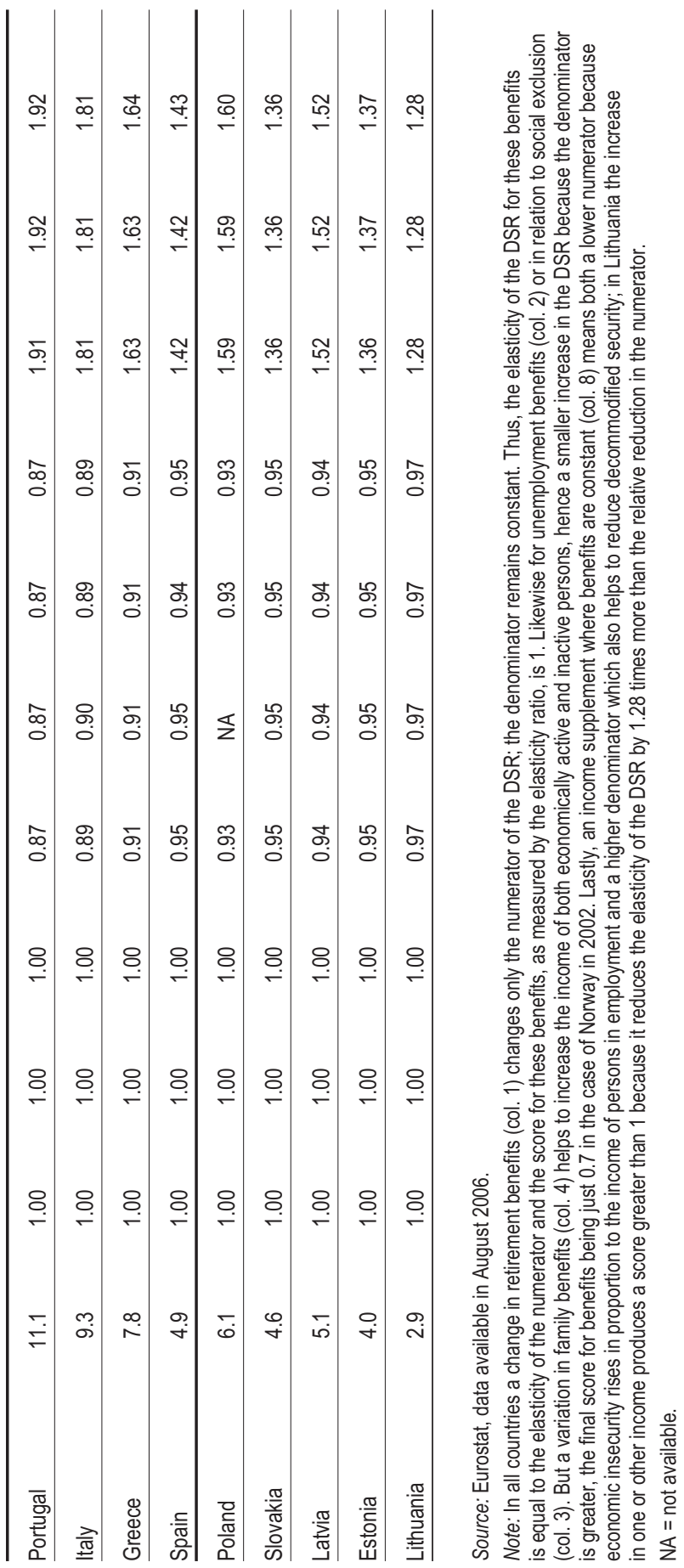


the level for Norway $(-0.70)$, the stronger penalization of the United Kingdom $(-1.16)$ can be explained largely by this second factor, while that of Spain $(-2.00)$ or Estonia $(-2.65)$ is due to a combination of the two.

\section{Three rationales determine the sensitivity of security to variations in its components}

Three different rationales emerge when we compare the sensitivities of decommodified security to the different benefits and income sources which determine it. The features of the three rationales for these components are illustrated in Table 3, which provides a synopsis of multiple data. ${ }^{17}$ It is notable that the elasticity ratio takes just three values for each country: a maximum score of 1 , for the three benefits paid only to persons not in employment (columns 1, 2, 3) and whose direct effects are not attenuated because they do not influence the income of economically active persons; a score of less than 1 for the four universal benefits (columns 4-7), the effect of which on security is attenuated by the fact that they push up the reference income, both through insecurity and the denominator; and a coefficient greater than 1 for the three incomes which do not contribute to decommodified security (columns 8, 9, 10), though increases in them nevertheless help to lessen the reduction which goes with economic insecurity (in proportion to the income of persons in employment) owing to division by the denominator, all things which help to reduce the DSR.18

The differences between the decommodified security scores of the various benefits suggest that policies directly targeted at persons not in employment contribute the most towards enhancing people's security. This finding is truer of the countries of the North and the intermediate countries, as we see from Table 3, which shows that the score for universal benefits rises as the DSR falls. In the central and eastern European countries, the score of more than 93 per cent for all benefits shows that all social policies contribute more or less equally to increasing people's security and improving social cohesion, in line with the recommendations of the Lisbon strategy.

17. To calculate the score for benefits and sensitivity to incomes, we simply calculate the elasticity ratio of the DSR and the elasticity ratio of the DSR numerator, for the ten components of the security-enhancing resources. This operation measures the total effects of benefits on decommodified security (both direct and indirect effects on the reference income against which security and insecurity are measured) as against the effect on the numerator alone. The calculation stages concern three terms: the elasticities of decommodified security (Table 2) and the elasticities of the DSR numerators and denominators (reproduced in the annex, Tables 4 and 5).

18. This coefficient cannot be interpreted as a score, because it assesses the indirect effect on decommodified security of increases in incomes which are not security-enhancing resources. 
In addition to differences between countries, the contrasts between these three rationales point to the importance of changes in the reference incomes against which people rate the benefits they receive. The security gains provided by a given amount of benefits are all the greater if they relate to measures associated with a more modest rise in the general level of incomes.

\section{Conclusions}

A review of the ways in which decommodified security is taken into account in the countries of Europe shows us that this dimension is of significant value to social States and can be identified differently in four groups of countries. Decommodified security is especially developed in the social democratic countries of the North, where social security achievements have become more of an established part of the institutional fabric in a manner largely independent of the labour market. This makes the term "decommodified", as applied to these forms of security, all the more appropriate. Another notable finding: social policies more founded on decommodified security in the North mean that people are better integrated by virtue of their entitlements as citizens, and this translates into poverty rates which are lower by half. In the United Kingdom and Portugal, however, where security is more "commodified" in the sense that it is more dependent on the labour market, the proportion of persons in poverty is twice as high as in the countries with a social democratic tradition. Nevertheless, it appears that a social tradition persists in the old-established social State of the United Kingdom, where the importance of social incomes inherited from the Beveridge Plan keeps the decommodified security ratio well above that of Italy. Lastly, we found that the level of decommodified security in the central and eastern European countries is low. All the more reason to attach importance to taking the security dimension into account when defining the social protection systems which these countries are preparing to develop.

In that context it may be useful to draw on our social policy simulations. These led us to identify two types of benefits: those aimed at persons not in employment, and universal benefits whose less targeted effects do less to increase the level of decommodified security. These two types of benefits further the convergence of social systems more when they are distributed in the countries of the South and the central and eastern European countries, whose systems are significantly less developed than in the social States of northern Europe. The greater score for benefits aimed at people not in employment, particularly benefits paid to combat exclusion, thus suggests which policies would be most likely to improve social cohesion, in line with the objectives of the Lisbon strategy. 
Our simulations also allowed us to demonstrate the importance of the links between redistribution policies and their indirect effects in determining reference incomes against which people measure their standard of living. They also revealed the complex relationships between poverty rates, perceived levels of insecurity and the breakdown of the population into persons in paid employment and self-employment and those not in employment. As trade and the means of production become more and more globalized, the deepening complexity of these relationships may be an increasingly topical issue.

\section{Bibliography}

Beck, U. 1986. Risikogesellschaft: Auf dem Weg in eine andere Moderne. Frankfurt, Suhrkamp. (Translated into English as Risk society: Towards a new modernity. London, Sage, 1992.)

Castel, R. 2003. L'insécurité sociale: qu'est-ce qu'être protégé? Paris, Seuil.

Corak, M. 2006. "Principles and practicalities for measuring child poverty", in International Social Security Review, Vol. 59, No. 2.

Esping-Andersen, G. 1990. The three worlds of welfare capitalism. Cambridge, Polity Press.

Euzéby, C. 2004. "Rethinking social security in the European Union: Extending fundamental universal rights", in International Social Security Review, Vol. 57, No. 1.

Gadrey, J.; Jany-Catrice, F. 2003. "Développement et progrès social, quels indicateurs choisir?", in Alternatives économiques, No. 211 (February).

Hobbes, T. 1651. Leviathan, or The matter, forme and power of a common wealth ecclesiasticall and civil. London.

Lewis, J. 1992. "Gender and the development of welfare regimes", in Journal of European Social Policy, Vol. 2, No. 3.

Locke, J. 1690. Second treatise of government. London.

Menahem, G. 2006. "Deux indicateurs du développement des droits sociaux: indicateur de démarchandisation versus taux de sécurité économique", in AES, Économie sociale et droit: XXVI es journées de l'Association d'économie sociale. Paris, l'Harmattan.

Menahem, G.; Cherilova, V. 2005. "Inégalités de sécurité économique et aide à la famille dans l'Union européenne", in Recherches et prévisions, No. 79 (March).

Merrien, F.-X.; Parchet, R.; Kernen, A. 2004. L'État social. Paris, Armand-Colin.

Mira d'Ercole, M.; Förster, M. 2005. Income distribution and poverty in OECD countries in the second half of the 1990s (OECD Social, Employment and Migration Working Paper, No. 22). Paris, OECD.

Orloff, A. S. 1993. "Gender and the social rights of citizenship: The comparative analysis of gender relations and welfare states", in American Sociological Review, Vol. 58, No. 3. 
Osberg, L.; Sharpe, A. 2002. "An index of economic well-being for selected OECD countries", in Review of Income and Wealth, Vol. 48, No. 3.

Polanyi, K. 1944. The great transformation. Boston, MA, Beacon Press.

Rhodes, M.; Palier, B. 1997. “Conclusion générale", in "Rencontres de Florence Comparer les systèmes de protection sociale en Europe du Sud", in Revue française des affaires sociales, Vol. 57, No. 4 (special issue).

Standing, G. 2002. "From People's Security Surveys to a Decent Work Index", in International Labour Review, Vol. 141, No. 4.

Strobel, P. 2003. "Présentation: le modèle nordique de protection sociale sous le choc des réformes", in "L'État providence nordique", in Revue française des affaires sociales, Vol. 57, No. 4 (special issue).

\section{Annex}

\section{Stages in calculation of the DSR and the score for benefit-derived security}

The DSR is an index which calculates a numerator, the sum of decommodified security-enhancing resources less economic insecurity, relative to a denominator, the mean disposable income of persons in employment. It is thus doubly useful to know the elasticities of the numerator (Table 4) and the denominator (Table 5).

This knowledge enables us first to understand the structural logic of DSR elasticity. Because the elasticity of a ratio is equal to the difference between the elasticity of the numerator and that of the denominator, each cell in Table 2 can be deduced logically from the difference between the equivalent cells in Tables 4 and 5. In Norway, for example, the elasticity of decommodified security in relation to total sickness benefits (column 8 ) is 0.28 according to Table 2 . When we see from Tables 4 and 5 that this figure is equal to the difference between the elasticity of the numerator $(0.40)$ and that of the denominator $(0.12)$, we understand better the reasons for the difference between the elasticity figures for Norway and for Lithuania (1.20, or the difference between 1.24 and $0.04)$, which is attributable to the very poor development of sickness benefits in the latter country.

Knowing the elasticity of the numerator (Table 4) then enables us, by measuring it against the elasticity of the DSR (Table 2), to assess its relative contribution, and thus the score for the various benefits ${ }^{19}$ in each country (Table 3 ). Thus, again in the case of Norway, Table 3 shows us that the score for sickness benefits $(0.70$ in column 8$)$ is equal to the ratio between the elasticity in Table $2(0.28)$ and that in Table 4 (0.70), which explains why it is lower than in Lithuania (where the score is 0.97 , or $1.20 / 1.24$ ).

19. This is more accurately the score for benefits net of their contribution to the increase in economic insecurity, which is taken into account in the numerator. We also calculated the gross scores for the various benefits and will be happy to make these available on request. The main thing to know is that they too are constant for all universal benefits and equal to 1 in the case of benefits for persons not in employment. 


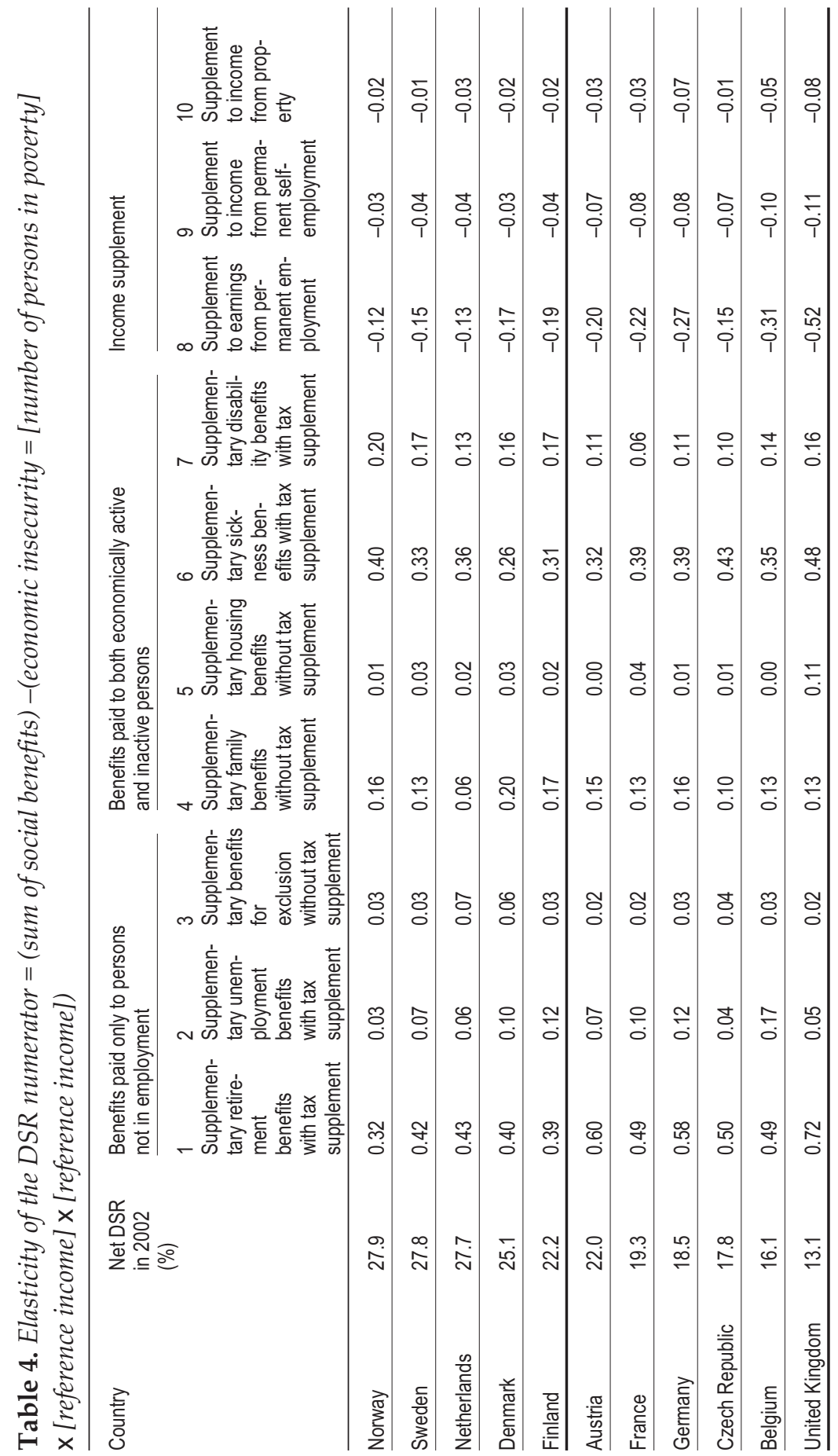




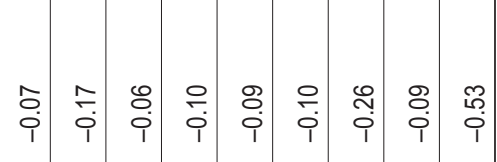

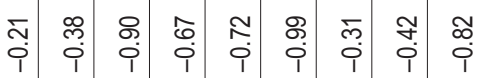

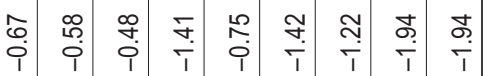

$$
\begin{aligned}
& \text { స్ల } \\
& \text { 满 } \\
& \text { 일 } \\
& \stackrel{m}{\stackrel{0}{0}} \text { : }
\end{aligned}
$$

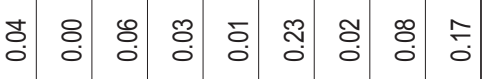

$$
\begin{aligned}
& \text { 盛 }
\end{aligned}
$$

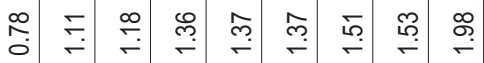

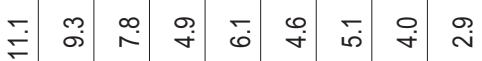

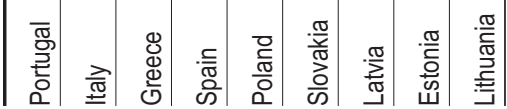




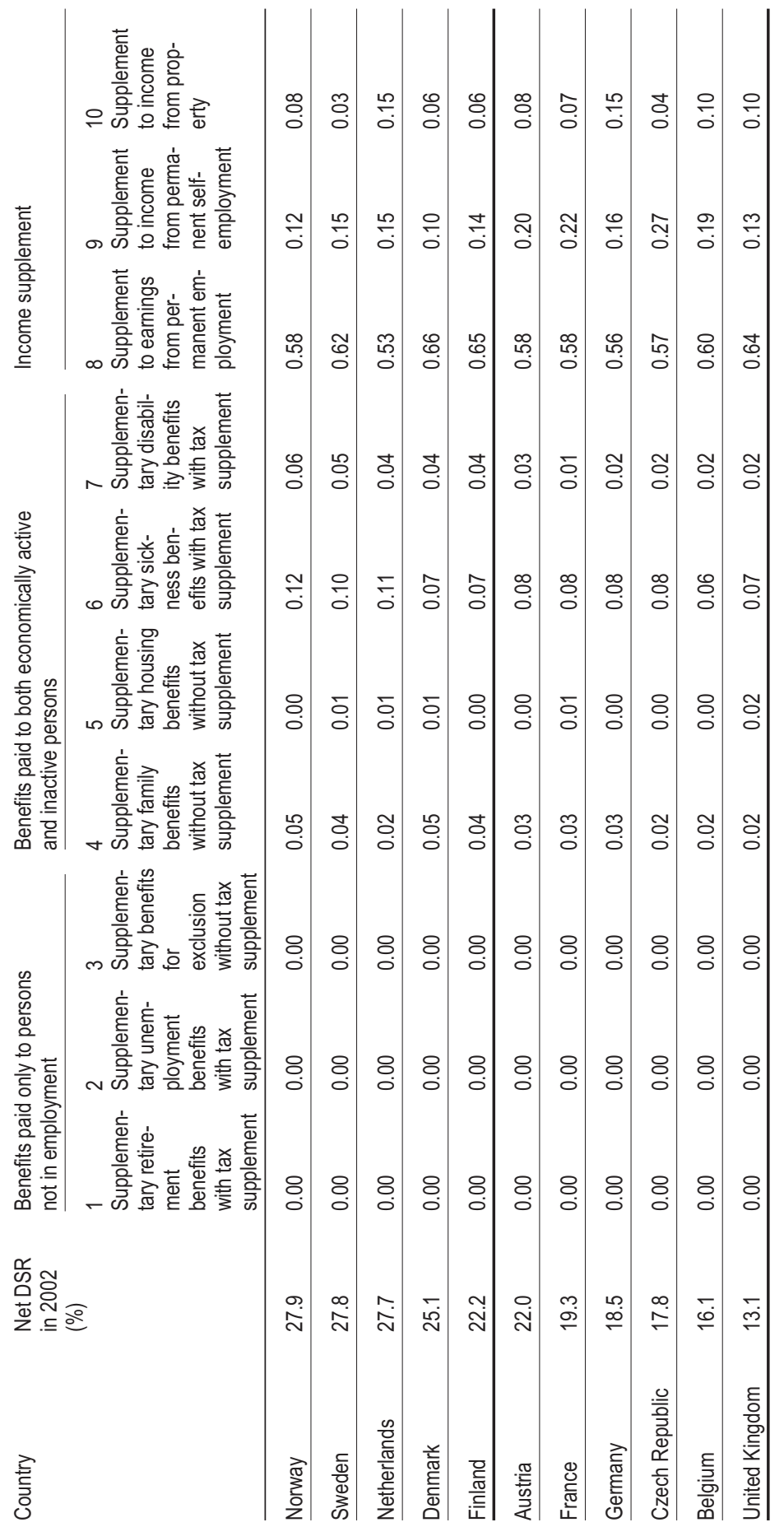




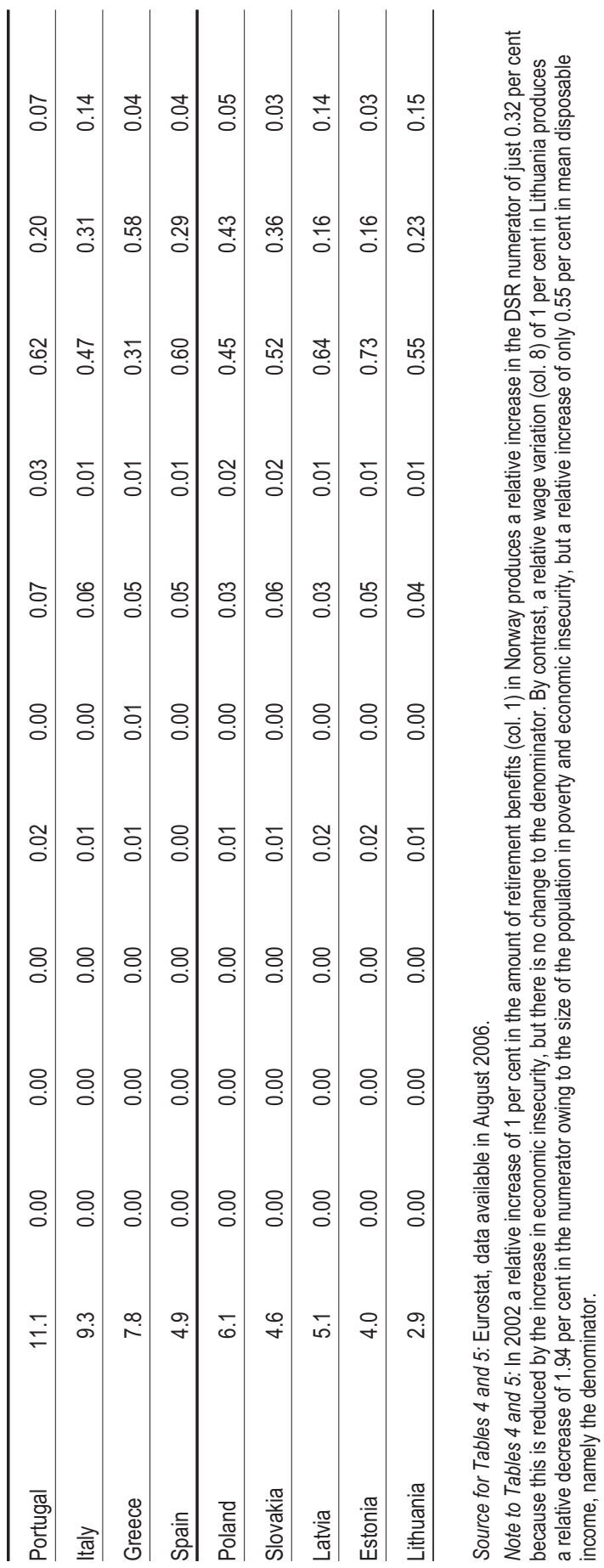

